\title{
PERFORMA PENETASAN TELUR AYAM HASIL PERSILANGAN AYAM BANGKOK DENGAN AYAM RAS PETELUR
}

\author{
${ }^{1}$ Rusli Badaruddin, ${ }^{1}$ Syamsuddin, ${ }^{1}$ Fuji Astuty, ${ }^{1)}$ Muh.Amrullah Pagala \\ ${ }^{1}$ Dosen Jurusan Peternakan Fakultas peternakan UHO Kendari \\ Email : ruslibadaruddin@gmail.com
}

\begin{abstract}
ABSTRAK
Penelitian ini bertujuan untuk mengkaji performa produksi telur dan reproduksi hasil persilangan ayam Bangkok dengan ayam Ras petelur.dilaksanakan di Laboratorium Unit Unggas Fakultas Peternakan Universitas Halu Oleo Kendari, pada bulan Juni sampai dengan Agustus 2017. Penelitian ini menggunakan ayam Bangkok betina sebanyak 15 ekor, ayam Bangkok jantan sebanyak 3 ekor, ayam Ras petelur jantan sebanyak 2 ekor dan ayam Ras petelur betina 15 ekor. Data yang diperoleh dianalisa secara deskriptif dan uji $\mathrm{T}$ untuk mengetahui perbedaan peubah-peubah anatara persilangan BP (Persilangan ayam Bangkok jantan dengan ayam Ras petelur betina) dan PB (Persilangan ayam Ras petelur jantan dengan ayam Bangkok betina). Hasil uji T menunjukkan bahwa hasil persilangan BP memiliki bobot telur, bobot tetas, produksi telur dan mortalitas emrio yang nyata $(p<0,05)$ lebih tinggi dibandingkan ayam PB, namun fertilitas dan daya tetas nyata $(p<0,05)$ lebih rendah serta indeks telur dan tebal kerang relatif sama.
\end{abstract}

Kata Kunci : Ayam Bangkok, Ayam Petelur, Persilangan.

\begin{abstract}
The research aim was to evaluate production and reproduction performance of Layer and Bangkok chicken. Research was conducted in Laboratorium Unit Unggas, Fakultas Peternakan, Universitas Halu Oleo Kendari, on July until August 2017. This research was using 15 birds' female Bangkok chicken, three birds' male Bangkok chicken, 15 birds' female Layer chicken, and two birds' male Layer chicken. The obtained data were analyzed descriptively and tested by $\mathrm{T}$ test to understand the parameters difference between crossed BP (male Bangkok and female layer crossing) and PB (male Layer and female Bangkok crossing). The $\mathrm{T}$ test result showed that $\mathrm{BP}$ crossing was have significant $(\mathrm{p}<0.05)$ higher of egg weight, hatching weight, egg production, and embryo mortality compare to PB crossing, however it's have significant $(\mathrm{p}<0.05)$ lower on fertility and hatch ability while their eggshell was similar.
\end{abstract}

Key Words : Bangkok Chickens, Layer, Crossbreeding 


\section{PENDAHULUAN}

Salah satu ternak yang banyak dibudidayakan oleh masyarakat Indonesia hingga perdesaan adalah ayam lokal. Pengembangan ayam lokal merupakan cara yang tepat untuk meningkatkan pendapatan petani. Beberapa faktor yang memberi kemudahan pemeliharaan ayam lokal, antara lain tidak membutuhkan lahan yang luas, penyediaan pakan mudah dan murah serta siklus produksi lebih singkat sehingga lebih cepat dirasakan manfaat ekonominya. Namun demikian, dalam usaha mengembangkan ayam lokal masih menghadapi berbagai kendala, antara lain sistem pemeliharaan masih tradisional, produktivitas rendah, baik produksi daging maupun produksi telur, variasi mutu genetik, tingkat kematian tinggi, pemberian pakan belum sesuai dengan kebutuhan baik kuantitas maupun kualitasnya.

Ayam Bangkok sudah termasuk menjadi ayam lokal karena telah lama dan banyak dibudidayakan oleh masyarakat Indonesia. Biasanya ayam Bangkok digunakan sebagai pejantan karena memiliki berbagai keistimewaan yaitu adalah bentuk tubuh yang ramping dan memiliki daya tahan berlaga yang tinggi. Disamping itu ayam Bangkok mempunyai nilai ekonomi yang tinggi. Tidak mengherankan apabila peternak kemudian memeliharanya untuk kepentingan bisnis bukan sekedar hobi dan kebanggaan.

Ayam petelur termasuk salah satu jenis ayam Ras penghasil telur yang cukup potensial. Produktivitas telur cukup tinggi yaitu $60-70 \%$. Penggunaan ayam petelur sebagai induk penghasil telur tetas sedangkan pejantannya menggunakan ayam Bangkok. Hal ini dimaksudkan agar telur yang dihasilkan dibuahi atau fertil, sebab bila telur tersebut tidak dibuahi akibatnya tidak akan menetas. Namun demikian tidak semua telur fertil akan menetas dengan dengan baik, banyak faktor yang berpengaruh di dalamnya. Sehubungan dengan hal ini maka untuk memperoleh daya tetas yang baik dalam penetasan.

Upaya perbaikan mutu genetik melalui persilangan yaitu untuk menghasilkan keturunan yang membawa sifat baik dari kedua tetua yang berbeda yakni kombinasi sifat dari pejantan dan betina. Persilangan ayam Bangkok dan Ras petelur dilakukan untuk menghasilkan keturunan yang memiliki kombinasi sifat baik kedua tetuanya yaitu ayam Bangkok dan ayam Ras petelur dengan terlebih dahulu mengamati reproduksi kedua jenis persilangan yakni Bangkok dengan petelur (BR) dan Ras petelur dengan Bangkok (RB).

\section{METODE PENELITIAN}

Penelitian dilaksanakan di Laboratorium Unit Unggas Fakultas Peternakan Universitas Halu Oleo Kendari.

Materi Penelitian yang digunakan adalah ayam Bangkok betina sebanyak 15 ekor, ayam Bangkok jantan sebanyak 3 ekor, ayam Ras petelur jantan sebanyak 3 ekor dan ayam Ras petelur betina 15 ekor.

Pakan yang diberikan selama penelitian ini terdiri atas jagung giling $50 \%$, dedak padi $15 \%$, dan kosentrat RK 24 produksi PT. Charoen Phokphand sebanyak $35 \%$ dengan kadar protein pakan $18 \%$.

Peralatan yang dibutuhkan adalah kandang ayam terbuat dari kayu dan bambu.Kayu sebagai tiang dan rangka sedangkan bambu sebagai sekat pada kandang.Model kandang yang dibuat yaitu batteray yang setiap petak berisi satu ekor ayam dengan ukuran perpetak $30 \times 30 \mathrm{~cm}$. Peralatan kandang yang digunakan berupa tempat pakan dan tempat minum terbuat dari pipa paralon 
yang dibagi dua. Alat kebersihan seperti sapu, kain pel, ember dan serokan sampah juga digunakan sebagai penunjang pemeliharaan.

Ruang data untuk menyimpan telur dilengkapi buku catatan, alat tulis, timbangan digital dan jangka sorong.Pada kegiatan penetasan dibutuhkan peralatan berupa mesin tetas semi otomatis berkapasitas 100 butir telur yang dilengkapi thermostat, thermometer, lampu, serta bak air.

\section{Prosedur Penelitian}

\section{Pemeliharaan}

Ayam Bangkok dan petelur dikandangkan secara terpisah. Perkawinan dilakukan secara IB (Inseminasi Buatan) berdasarkan persilangan ayam Bangkok jantan dengan ayam petelur betina (BP) serta persilangan ayam petelur jantan dengan ayam Bangkok betina (PB) digunakan perbandingan 1 jantan : 5 betina (1:5), sehingga terdapat 2 ulangan pada (PB) dan 3 ulangan pada (BP). Ayam diberi pakan ad libitum yaitu pada pagi dan sore di setiap 1 kandang ulangan dengan pemberian maksimal 200 g/ekor/hari, air minum diberikan ad libitum di setiap 1 kandang ulangan. Alas kandang adalah sekam padi. Sekam diganti saat sekam basah dan menggumpal. Pencegahan penyakit dilakukan dengan cara menjaga kebersihan kandang dan lingkungan sekitar kandang serta meminimalisir masuknya penyakit dari luar kandang dengan melepas atau mengganti alas kaki saat memasuki kandang. Pencegahan stres ayam dilakukan dengan menggunakan pakaian warna putih saat masuk ke dalam kandang. Ayam yang cidera atau sakit dipindahkan kekandang lain untuk pengobatan hingga ayam kembali pulih (medikasi). Vaksinasi juga dilakukan pada bulan Juni dan Mei 2017 yaitu vaksinasi ND (Newcastle Disease) dan AI (Avian Influenza).

\section{Pengumpulan Telur Tetas dan Penetasan}

Telur mulai dikoleksi dan diambil data pada saat minggu kedua ayam berada di kandang penelitian.Telur tetas dikumpulkan dari kandang ayam minimal 3 kali sehari.Telur dibersihkan dengan pisau untuk melepaskan kotoran yang menempel dan kain lap kering untuk menghilangkan debu kotoran yang telah dikikis tanpa harus menipiskan kerabang kemudian telur tetas diberi kode sesuai nomor urutan telur dikoleksi.Kode telur untuk jenis ayam silangan terdapat 2 macam yaitu untuk telur dari ayam Bangkok jantan dengan petelur betina (BP) dan untuk telur dari ayam petelur jantan dengan Bangkok betina (PB).Telur ditimbang menggunakan timbangan digital dan diukur panjang dan lebarnya (mm) menggunakan jangka sorong.

Telur yang ditetaskan adalah telur dengan kisaran penyimpanan 1-7 hari.Sebelum ditetaskan telur diseleksi dengan parameter keutuhan kerabang, bobot telur dan tidak kotor.Telur tetas ditata vertikal ke dalam rak telur dan diganjal menggunakan kertas atau karton bekas hingga tidak ada ruang yang longgar agar telur tidak jatuh saat pemutaran telur berlangsung, kemudian rak telur dimasukkan ke dalam mesin tetas.Selama penetasan suhu dan kelembaban mesin tetas dicatat dan dijaga agar tetap optimal.Kelembaban dijaga dengan mengisi bak air dan diisi kembali saat air sudah berkurang.Pemutaran telur dilakukan setiap hari yaitu 3 kali dalam sehari. Pada inkubasi hari ke-7, telur diteropong untuk mengetahui fertilitas telur tetas, sedangkan hari ke-18 telur dipindahkan ke dalam rak telur hatcher untuk persiapan telur akan menetas. Saat telur menetas, DOC ditimbang setelah bulu kering dan diperiksa kondisi kesehatan dan keutuhan DOC. Kerabang telur diukur ketebalannya di bagian tumpul, 
tengah, dan lancip kerabang untuk mendapatkan rataan ketebalan kerabang.

\section{Analisis Data}

Data dianalisa secara deskriptif dan uji $\mathrm{T}$ untuk mengetahui perbedaan peubah-peubah anatara persilangan $\mathrm{BP}$ dan PB.

$$
\mathrm{Uji} T=\frac{(\overline{\mathrm{y}} 2-\overline{\mathrm{y}} 1)-(\mu 2-\mu 1)}{s\left(\sqrt{\frac{1}{n 2}}+\sqrt{\frac{1}{n 1}}\right)}
$$

Keterangan :

$$
1 \text { = rataan sampel } 1
$$

2 = rataan sampel 2

$\mu 1=$ rataan populasi 1

$\mu 2=$ rataan populasi 2

$\mathrm{n} 1$ = banyak sampel 1

$\mathrm{n} 2$ = banyak sampel 2

$\mathrm{S}=\operatorname{akar} \mathrm{KT}(\mathrm{G})$

\section{E. Peubah yang Diamati}

\section{Karakteristik Telur Tetas}

a. Bobot telur tetas ( $\mathrm{g} / \mathrm{butir})$

b. Indeks telur $=\frac{\text { lebar }}{\text { panjang }} \times 100 \%$

c. Ketebalan kerabang, rataan kerabang yang menetas diukur tanpa kulit kerabang ( $\mathrm{mm} /$ butir).

d. Bobot tetas DOC (Day Old Chick) (g/ekor).

\section{Performa Reproduksi}

\section{a. Hen day $(\%)$}

$\frac{\text { Jumlah telur yang diproduksi }}{\text { Jumlah ayam produktif }} \times 100 \%$

b. Fertilitas (\%)

$$
\begin{gathered}
\frac{\text { Jumlah telur fertil }}{\text { Jumlah telur yang dimasukkan }} \\
\text { kedalam mesin tetas }
\end{gathered}
$$

c. Daya Tetas (\%)

$\frac{\text { Jumlah telur yang menetas }}{\text { Jumlah telur yang fertil }} \times 100 \%$

d. Mortalitas (\%)

$\frac{\text { Jumlah embrio telur yang mati }}{\text { Jumlah telur yang fertil }} \times 100 \%$

\section{HASIL DAN PEMBAHASAN}

\section{A. Karakteristik Telur Tetas}

Karaktersitik telur tetas yang diamati pada penelitian ini yaitu bobot telur tetas, indeks telur, tebal kerabang dan bobot tetas yang disajikan pada Tabel 1.

\section{Bobot Telur Tetas}

Bobot telur sering digunakan sebagai kriteria seleksi untuk telur tetas.Kriteria bobot telur menurut SNI (2008) dimasukkan ke dalam 3 kelas yakni besardengan bobot telur lebih dari 60 g/butir, sedang yaitu telur dengan bobot 50-60 g/butir, dan kecil yaitu telur dengan bobot kurang dari $50 \mathrm{~g} /$ butir.

Pada Tabel 1, menunjukkan bahwa rataan bobot telur PB 46,57 g/butir (kecil) nyata $(p<0,05)$ lebih tinggi dibandingkan pada BP 59,40 g/butir (sedang). MenurutDitjennak (2006) bahwa rataan bobot telur ayam kampung yang dipelihara secaraintensif adalah 40 g/butir. Menurut Putri (2014), ayam kampung yang disilangkan dengan ayam pedaging memiliki rataan bobot telur sebesar $59.41 \mathrm{~g} /$ butir (sedang).

Tingginya bobot telur pada ayam $\mathrm{BP}$ dibandingkan telur ayam $\mathrm{PB}$, hal ini dikarenakan faktor oleh genetik (Ensminger dkk., 2004). Faktor genetik berpengaruh terhadap lama periode pertumbuhan ovum sehingga yolk yang lebih besar akan menghasilkan telur yang lebih besar. Campbell dkk.(2003) juga menambahkan besar ayam, umur, dan nutrisi juga mempengaruhi bobot telur.Faktor-faktor yang mempengaruhi bobot telur terutama adalah induk, seperti bobot badan induk, umur, serta kualitas dan kuantitas konsumsi pakan (Achmanudkk., 2011). 
Tabel 1.Karakteristik Telur Tetas Ayam dari Hasil Persilangan antara PB dan BP

\begin{tabular}{clcc}
\hline \multirow{2}{*}{ No } & \multicolumn{1}{c}{ Parameter } & \multicolumn{2}{c}{ Persilangan Ayam } \\
\cline { 3 - 4 } & & PB & BP \\
\hline $\mathbf{1}$ & Bobot Telur Tetas (g/butir) & $46,57 \pm 1,34^{\mathrm{b}}$ & $59,40 \pm 0,49^{\mathrm{a}}$ \\
$\mathbf{2}$ & Indeks Telur (\%) & $76,85 \pm 7,69$ & $77,18 \pm 2,59$ \\
$\mathbf{3}$ & Tebal Kerabang (mm) & & \\
& Atas & 0,41 & 0,39 \\
& Tengah & 0,40 & 0,41 \\
& Bawah & 0,41 & 0,38 \\
& Total & $0,41 \pm 0,05$ & $0,40 \pm 0,05$ \\
$\mathbf{4}$ & Bobot Tetas (g/ekor) & $29,67 \pm 0,63^{\mathrm{b}}$ & $38,49 \pm 0,43^{\mathrm{a}}$ \\
\hline
\end{tabular}

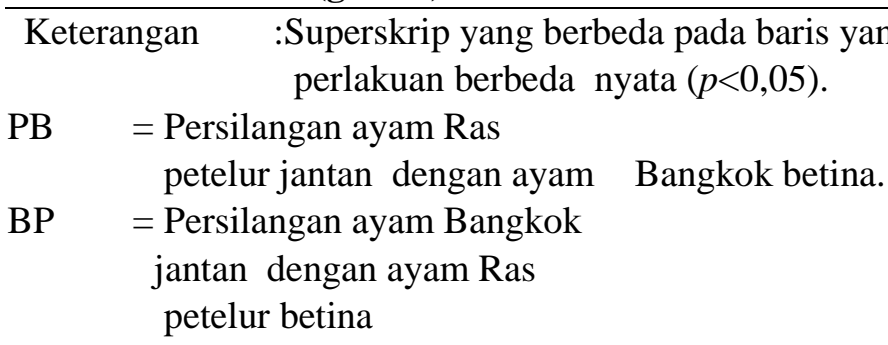

\section{Indeks Telur}

Pada Tabel 1, terlihat bahwa indekes telur pada ayam PB dan BP memiliki rataan yang relatif sama yaitu $76,85-77,18 \%$. Kisaran indek telur pada penelitian ini masuk dalam kisaran normal $69-77 \%$ (Zainuddin dan Jannah, 2014). Selanjutnya dijelaskan bahwa nilai indeks telur merupakan suatu indikasi untuk mengetahui tingkat kelonjongan atau bulatnya bentuk telur, dimana semakin besar angka indeks telur maka bentuk telur akan semakin lonjong. Kisaran indeks telur yang normal adalah 0,70-0,74. Septiawan (2007) bentuk telur dipengaruhi oleh lebar tidaknya diameter isthmus. Semakin lebar diameter isthmus, maka bentuk telur yang dihasilkan cenderung bulat dan apabila diameter isthmus sempit, maka bentuk telur yang dihasilkan cenderung lonjong.

\section{Tebal Kerabang}

Pada Tabel 1, terlihat bahwa tebal kerabang pada ayam BP dan PB memiliki rataan yang relatif sama. Menurut Juliambarwati dkk.(2012) bahwa tebal kerabang dipengaruhi kandungan Kalsium (Ca) dan Fosfor (P) dalam ransum berperan terhadap kualitas kerabang telur dalam pembentukan kerabang telur diperlukan adanya ion-ion karbonat danion-ion $\mathrm{Ca}$ yang cukup untuk membentuk $\mathrm{CaCO} 3$ kerabang telur.Wiradimadja dkk. (2010), faktor yang mempengaruhi tebal kerabang diataranya adalah kalsium ransum yang berkisar 4,60-4,67\% dengan imbangan kadar fosfor yang tersedia antara 1,74$1,90 \%$. Lebih lanjut dijelaskan bahwa faktorlain yang juga turut mempengaruhi tebal kerabang yaitu sifat genetik, ransum, umur ayam dan suhu lingkungan. Rataan tebal kerabang yang diperoleh pada penelitian ini yaitu $0,40-0,41 \mathrm{~mm}$, hasil ini dibandingkan penelitian Widjaja (2001) antara 0,33 sampai $0,36 \mathrm{~mm}$. Menurut Wiradimadja dkk. (2010), ketebalan kerabang telur jangan kurang dari $0,33 \mathrm{~mm}$. Kerabang telur yang tipis relatif berpori lebih banyak dan besar, sehingga mempercepat turunnya kualitas telur yang terjadi akibat penguapan (Haryono, 2000). 


\section{Bobot Tetas}

Pada Tabel 1, terlihat bahwa bobot tetas ayam BP 38,49g/butir lebih tinggi dibandingkan dengan aym PB $29,67 \mathrm{~g} /$ butir, hal ini dikerenakan adanya hubungan yang erat antara bobot telur dengan bobot tetas. Saepudin (2015) juga menyatakan berat telur tetas berpengaruh terhadap berat tetas. Menurut Rahayu (2014) bahwa salah satu yang mempengaruhi bobot tetas yaitu bobot telur. Telur dengan bobot rata-rata atau sedang akan menetas lebih baik daripada telur yang terlalu kecil dan terlalu besar Ahyodi dkk., 2014).

Sadid (2016) faktor yang mempengaruhi bobot tetas adalah genetik, pakan, berat telur dan lingkungan. Suhu yang tinggi dan kelembaban rendah dapat menyebabkan bobot tetas dihasilkan menurun (Nuryati dkk.2000). Penetasan telur menggunakan mesin otomatis dengan suhu antara 37$38^{\circ} \mathrm{C}$. (misal : telur puyuh masa inkubasi17 hari, ayam 21 hari, itik 28 hari) berkisar antara $36-39^{\circ} \mathrm{C}$ (Siboro, 2016).

\section{B. Performa Reproduksi}

Performa produksi yang diamati pada penelitian ini yaitu hen day production, fertilitas, daya tetas dan mortalitas embrio yang disajikan pada Tabel 2.

\section{Hen Day Production}

Pada Tabel 2, terlihat bahwa Hen day Production persilangan ayam BP $77,42 \%$ lebih tinggi dibandingkan dengan ayam PB 63,33\%.Ayam Ras petelur secara genetik memiliki produksi telur yang lebih tinggi dibandingkan dengan ayam lokal.Menurut Sajuti (2016) bahwa ayam local memiliki ketahanan yang lebih baik terhadap penyakit, terutama AI, dibandingayamras. Namun demikian ayam local mempunyai beberapa keterbatasan budidaya antara lain pertumbuhan bobot badan yang relatif lambat, produksi telur yang relatif rendah dibandingkan ayam ras, angka konverci makanan dan angKa kematian yang tinggi.

Produktivits ayam secara genetik dipengaruhi oleh beberapa gen penting seperti gen $\mathrm{GH}$ untuk pertumbuhan dan produksi telur (Pagala dkk, 2013; pagala dkk, 2015). Nataamijaya(2008), produksi telur ayam kampung berkisar antara 20$30 \%$ pada sistem pemeliharaan intensif, sedangkan ayamras petelur mencapai henday production $73 \%$.Berdasarkan pendapat tersebut ayam betina Bangkok memiliki potensi untuk dikembangkan menjadi ayam tipe petelur.Telur yang nantinya dihasilkan memiliki nilai ekonomi yang lebih tinggi dibandingkan ayam ras petelur.

Tabel 2. Performa Reproduksi Ayam dari Hasil Persilangan antara PB dan BP

\begin{tabular}{clcc}
\hline \multirow{2}{*}{ No } & \multicolumn{1}{c}{ Parameter } & \multicolumn{2}{c}{ Persilangan Ayam } \\
\cline { 3 - 4 } $\mathbf{1}$ & Hen Day (\%) & $63,33 \pm 10,61^{\mathrm{b}}$ & $77,42 \pm 10,21^{\mathrm{a}}$ \\
$\mathbf{2}$ & Fertilitas (\%) & $74,44 \pm 8,39^{\mathrm{a}}$ & $62,22 \pm 3,85^{\mathrm{b}}$ \\
$\mathbf{3}$ & Daya Tetas (\%) & $76,24 \pm 3,64^{\mathrm{a}}$ & $65,93 \pm 4,49^{\mathrm{b}}$ \\
$\mathbf{4}$ & Mortaitas Embrio (\%) & $23,76 \pm 3,64^{\mathrm{b}}$ & $34,07 \pm 4,49^{\mathrm{a}}$ \\
Keterangan $\quad$ :Superskrip yang berbeda pada baris yang sama menunjukkan \\
\multicolumn{3}{c}{ perlakuan berbeda nyata $(p<0,05)}$. \\
\hline PB & = Persilangan ayam Ras & \\
\multicolumn{3}{c}{ petelur jantan dengan ayam } & Bangkok betina. \\
BP & = Persilangan ayam Bangkok &
\end{tabular}




\section{Fertilitas}

Pada Tabel 2, terlihat bahwa fertilitas persilangan ayam PB $74,44 \%$ nyata $(p<0,05)$ lebih tinggi dibandingkan dengan persilangan ayam BP $62,22 \%$. Rendahnya fertilitas pada ayam BP kemungkinan dipengaruhi oleh faktor umur induk ( 2 tahun) yang suda berada pada puncak produkitif. Masa produktif ayam petelur yaitu 1-2 tahun (Darmawan dan Sitanggang, 2002). Zainuddin dan Jannah, (2014), umur sangat mempengaruhi ovulasi, dimana ovulasi meningkat cepat dari masa sebelum dewasa ke titik yang tertinggi dan kemudian secara lambat akan menurun kesterilitas masa tua. Menurut Ankanegara (2011), faktor-faktor yang mempengaruhi fertilitas adalah cahaya, rasio jantan dan betina, umur ternak, interval antara waktu perkawinan dan penyimpanan telurtetas, pakan, abnormalitas spermatozoa, produksi telur, bangsa dan musim.

Selain itu penurunan suhu akibat listrik yang padam memnyebabkan panas dalam mesin tetas tidak stabil sehingga fertilitas telur menurun. Menurut Maghfiroh dkk. (2015) bahwa lingkungan ruangan mesin penetas telur (suhu dan kelembapan) yang kurang sesuai dapat mempengaruhi tingkat fertilitas telur.Suhu mesin tetas diatur pada kisaran $38-39^{\circ} \mathrm{C}$ dengan kelembaban 45-60\% (Asmarawati dkk., 2013).

\section{Daya Tetas}

Pada Tabel 2, terlihat bahwa daya tetas ayam PB nyata $(p<0,05)$ lebih tinggi dibandingkan pada ayam BP. Rendahnya daya tetas pada ayam BP, hal ini dikarenakan dipengaruhi oleh manajemen penetasan (suhu mesin tetas) dan umur ayam Ras Petelur yang digunakan sebagai induk. Menurut Rahayu dkk.(2005) bahwa faktor-fakor yang mempengaruhi daya tetas yaitu penyimpanan telur, faktor genetik, suhu dan kelembapan, musim, nomor induk, kebersihan induk, kebersihan telur, ukuran telur dan nutrisi. Suhu dan kelembapan yang sama juga menyebabkan daya tetas yang relatif sama. Suhu yang terlalu tinggi dapat menyebabkan gangguan syaraf, jantung, pernapasan, ginjal, dan membran embrio mengering sehingga membunuh embrio sedangkan suhu yang rendah pada penetasan menyebabkan pertumbuhan yang tidak proporsional. Suhu rendah juga dapat menyebabkan gangguan jantung, pernapasan, dan gizi yang tidak dapat diserap oleh embrio (Ahyodi dkk., 2013).

\section{Mortalitas Embrio}

Mortalitas embrio pada ayam BP yaitu sebesar 34,07\%, sedangkan pada ayam PB didapatkan mortalitas embrio lebih rendah yaitu sebesaar $23,76 \%$. Mortalitas embrio pada penelitian ini diakibatkan listrik yang padam sehingga menyebabkan tidak stabilnya sumber panas mesin tetas .Hafsah dkk.(2008), Suhu merupakan salah satu faktor yang sangat penting dalam menentukan atau mempengaruhi perkembangan embrio, daya tetas, dan pertumbuhan anak setelah menetas. Jasa (2006), suhu embrio harus sesuai dengan kondisi pada proses penetasan alami menggunakan induk, adapun kisaran suhu dalam mesin tetas yaitu sebesar $95-104^{0} \mathrm{~F}$.

\section{KESIMPULAN}

Fertilitas daya tetas dan mortalitas embrio yang terbaik diperoleh pada ayam PB (Persilangan ayam Raspetelur jantan dengan ayam Bangkok betina), namun produksi telur, bobot telur dan bobot tetas yang terbaik diperoleh pada ayam BP (Persilangan ayam Bangkok jantan dengan ayam Ras petelur betina). 


\section{DAFTAR PUSTAKA}

Ankanegara, A. A. 2011. Fertilitas telur ayam arab hasil inseminasi buatan menggunakan semen dari frekuensi penampunan berbeda.Skripsi. Fakultas Peternakan. Institut Pertanian Bogor, Bogor.

Ahyodi, F., K. Nova dan T. Kurtini.2104. Pengaruh bobot telur terhadap fertilitas, susut tetas, daya tetas, dan bobot tetas telur kalkun. Jurnal Ilmiah Peternakan Terpadu, 2(1).

Asmarawati, W., D. T. Widayati, dan S. Bintara.Pengaruh dosis sperma yang diencerkan dengan nacl fisiologis terhadap fertilitas telur pada inseminasi buatan ayam kampung.Buletin Peternakan, 37(1): $1-5$.

Campbell, J.R., M.D. Kenealy, K.L. Campbell. 2003. Animal Science. The Biology,Care, and Production of Domestic Animal. Ed ke-4. New York (US): Mc.Graw Hill.

Darmawan, W. dan Sitanggang, M. 2002. Meningkatkan produktivitas ayam arab petelur. AgroMedia.

Direktorat Jendral Peternakan. Departemen Pertanian. 2006. Pedoman pembibitan ayam kampung yang baik. Ditjennak, Jakarta.

Ensminger ME, G. Brant, C.G. Scanes. 2004. Poultry Science. Ed ke-4. New York (US): Pearson Prentice Hall.

Hafsah, H., Yuwanta, T., Kustono, K., dan Djuwantoko, D. 2008. Karakteristik habitat mikro sebagai dasar pola penetasan telur maleo di taman nasional lore lindu sulawesi tengah. Agroland, 15(3): 223-228.

Haryono. 2000. Langkah-Langkah Teknis Uji Kualitas Telur Konsumsi Ayam Ras. Temu teknis
Fungsional non Peneliti. Balai Penelitian Ternak, Bogor.

Jasa, L. 2006. Pemanfaatan mikrokontroler atmega 163 pada prototipe mesin penetasan telur ayam.Jurnal Teknologi Elektro, 5(1):30-36.

Juliambarwati, M., Ratriyanto, A., dan Hanifa, A. 2012.Pengaruh penggunaan tepung limbah udang dalam ransum terhadap kualitas telur itik.Sains Peternakan: Jurnal Penelitian Ilmu Peternakan, 10(1): 1-6.

Maghfiroh, F., Kurtini, T., dan Nova, K. 2015. Pengaruh dosis larutan vitamin b kompleks sebagai bahan penyemprotan telur itik tegal terhadap fertilitas, susut tetas, daya tetas, dan kematian embrio.Jurnal Ilmiah Peternakan Terpadu, 3(4).

Nataamijaya, A. G. 2008. Karakteristik dan produktivitas ayam kedu hitam.Buletin Plasma Nutfah,14(2): 85-89.

Nuryati, T., Sutarto, M. Khaim, dan P. S.Hardjosworo. 2000. Sukses MenetaskanTelur. Penebar Swadaya. Jakarta. Pagala, M.A., Muladno, C.Sumantri \& S. Murtini. 2013.Association of $\mathrm{Mx}$ Gene Genotype with Antiviral and Production Traits in Tolaki Chicken.Int. J. Poult Sci. 12 (12): 735-739.

Pagala, MA, AM.Tasse, N.Ulupi. 2015. Association of cGH EcoRV Gene with Production in Tolaki Chicken. IJSBAR. 24(7):88-95.

Putri, A.E. 2014.Performa penetasan telur ayam hasil persilangan ayam kampung dengan ayam ras pedaging.Skripsi. Fakultas Peternakan. Institut Pertanian Bogor, Bogor. 
Rahayu, C.T. 2014.Performa produksi dan reproduksi persilangan ayam sentul

dengan kampung serta pelung dengan sentul.Skripsi. Fakultas Peternakan. Institut Pertanian Bogor, Bogor.

Sadid, S. I. 2016. Fertilitas, daya tetas, dan bobot tetas ayam lokal jimmy's farm cipanas kabupaten cianjur jawa barat. Students $e$ Journal, 5(4): 1-10.

Sajuti, R. 2016. Analisis agribisnis ayam buras melalui pendekatan fungsi keuntungan multi output kasus Jawa Timur. Jurnal Agro Ekonomi, 19(2): 56-74.

Septiawan, R. 2007. Responproduktivitas dan reproduktivitasayam kampung dengan umurinduk yang berbeda.Skripsi.Fakultas

Peternakan. InstitutPertanian Bogor, Bogor.

Siboro, N. 2016.Pengaruh umur induk itik dan spesific gravity terhadap karakteristik tetasan.Students $e$ Journal, 5(4): 1-7.
Soepuddin, A. 2015.Performa produksi telur dan reproduksi hasil persilangan ayam lokal dengan ayam ras pedaging.Skripsi. Fakultas Peternakan. Institut Pertanian Bogor, Bogor.

Standar Nasional Indonesia Nomor 39262008. 2008. Telur Ayam Konsumsi. Jakarta: Badan Standarisasi Nasional.

Widjaja, H. 2001. Seandainyai Telur Bisa Bicara. Poultry Indonesia.Hal.4446.

Wiradimadja, R., Burhanuddin, H., dan Saefulhadjar, D. 2010. Peningkatan kadar vitamin a pada telur ayam melalui penggunaan daun katuk (Sauropus androgynus L. Merr) dalam Ransum. Jurnal Ilmu Ternak, 10(2): 90-94..

Zainuddin, D. dan Jannah, I. R. (2014).Suplementasi Asam Amino Lisin dalam Ransum Basal untuk Ayam Kampung Petelur terhadap Bobot Telur, Indeks Telur, Daya Tunas dan Daya Tetas serta Korelasinya.JITV, 19(3):142-148. 